\title{
Municipal Social Responsibility of Statutory Cities in the Czech Republic
}

\author{
Libena Tetrevova *(1) and Martina Jelinkova \\ Department of Economy and Management of Chemical and Food Industries, Faculty of Chemical Technology, \\ University of Pardubice, Studentska 95, 53210 Pardubice, Czech Republic; martina.jelinkova@upce.cz \\ * Correspondence: libena.tetrevova@upce.cz; Tel.: +420-46-6036661
}

Received: 3 April 2019; Accepted: 14 April 2019; Published: 17 April 2019

\begin{abstract}
Application of the concept of corporate social responsibility (CSR) is demanded of an ever-wider range of entities as time goes by, among which are municipalities. However, the topic of social responsibility of municipalities stands outside of the bounds of mainstream research. This article presents the results of a study, the objective of which was to identify the socially responsible practices applied by the statutory cities in the Czech Republic, in order to analyse and evaluate the scope and structure of socially responsible activities performed by them and communicated on the internet. The study shows that statutory cities in the Czech Republic perform similar activities to those performed by enterprises within the framework of application of the concept of CSR, this being in the field of economic, environmental, ethical, social and philanthropic responsibility. They perform and communicate economic responsibility activities to the greatest extent and, by contrast, ethical responsibility activities to the least extent. Examples of good practice in performance and communication of these activities on the internet are documented in the article using the example of the City of Pardubice.
\end{abstract}

Keywords: municipal social responsibility; municipal stakeholders; socially responsible activities; socially responsible communication; Czech Republic; Pardubice City

\section{Introduction}

Social responsibility (SR) is a topic that has been widely elaborated on from the point of view of corporations, see more e.g., in [1-4]. For several decades, more precisely since 1953, when H. R. Bowen [5], the so-called "Father of Corporate Social Responsibility" [2] (p. 270), laid the foundations of the modern concept of corporate social responsibility (CSR), its theoretical premises have been elaborated and practical experience relating to application of this concept discussed. Application of socially responsible behaviour is, however, also possible and desirable from the point of view of other types of organizations [6-9]. Nejati et al. [7] support this notion with the idea that everyone and everything is directly or indirectly affected by an organization's activities. The activities of organizations influence their surroundings (stakeholders, society, and other influenced parties) and they thus need to take responsibility in some way [7]. Apart from enterprises of all sizes and legal forms, these organizations could also be public administration organizations, e.g., ministries, regional or municipal authorities $[8,9]$ and universities $[6,10]$, but also other entities from the public and third sector.

The fact is that whereas a great deal of attention is paid to the issue of CSR, the issue of SR in other types of organizations stands outside the bounds of mainstream research [11]. It is thus necessary to support wider discussion of this topic and to broaden knowledge in this field. This is to say that application of socially responsible behaviour from the point of view of public authorities, i.e., among others, from the point of view of municipal authorities, seems to be especially important. As Crowther 
and Aras [12] (p. 12) state, "the central tenet of social responsibility is the social contract between all the stakeholders to society, which is an essential requirement of civil society". Moreover, municipalities' duties are nearly the same as the nature of socially responsible activities. In developed and several developing countries, the demand for development of socially responsible behaviour by all types of economic entities is exhibiting itself to an ever-greater degree. In the Czech Republic for example, it is important for $79 \%$ of employees whether their employer is socially responsible and $68 \%$ of people are willing to pay more for environmentally friendly products [13]. Thanks to adoption and application of a concept of SR, public authorities can create positive effects not only for their stakeholders, but also for society as a whole or for themselves in the event of their effective communication. However, public authorities can also play a significant role in supporting socially responsible behaviour among other economic entities $[8,14,15]$. Other reasons leading towards the need for the application of socially responsible behaviour by public institutions include increasing demand for the quantity and quality of information provided by public authorities, increasing efforts to involve the public in the process of public inspection, or last but not least growing pressure on increasing the efficiency of public authorities while securing public goods [11]. Thanks to this, application of municipal social responsibility concept is a source of sustainable economic growth and competitiveness, not only for the entities involved, but also for regions and countries.

The aim of the survey was to identify the socially responsible practices applied by the statutory cities in the Czech Republic, in order to analyse and evaluate the scope and structure of socially responsible activities performed by them and communicated on the internet. The article is conceived as follows. The concept of municipal social responsibility (MSR) is discussed in the context of CSR and alternative views are presented of socially responsible areas and activities. Mention is also made of the benefits of application of the concept of MSR in the context of MSR communication. Explanation is provided in the third part of the method of data collection and methodology used. The results of the research are interpreted in part four. Evaluation is performed both at the level of application of the concept of MSR by the statutory cities in the Czech Republic and also the level of their MSR communication. A case study is also cited, presenting examples of good practice in the application of socially responsible practices, this being from the point of view of the Statutory City of Pardubice. The last part contains discussion and conclusions.

\section{Literature Review}

\subsection{Definition of Municipal Social Responsibility (MSR)}

The term SR has been defined by several individual authors (e.g., [5]) and institutions (e.g., [16-18]). Most definitions define the term SR of commercial entities. For example Davis and Blomstrom [19] state that businessmen apply socially responsible behaviour when they consider the needs and interest of others who may be affected by their actions, i.e., stakeholders. Their behaviour is beyond that prescribed by law and union contract [20].

The definition of SR of public sector organizations is dealt with by Pauzuoliene and Mauriciene [8] (p. 141), who state that "in the context of public sector organizations social responsibility should be viewed as a way of conducting business which enables the creation and distribution of wealth for the betterment of its stakeholders through the implementation and integration of ethical systems and sustainable management practices". Yarimoglu et al. [9] then focus specifically on municipal social responsibility applied by municipalities, if apart from their mandatory and discretionary duties they perform activities relating to the environment, education, culture, and health.

As is evident from that stated above, but also from the work of Dahlsrud [3], definitions of SR have various aspects in common. First and foremost, this concerns mention of stakeholders. This also concerns definition of the field of SR, when regular mention is made of the economic, social and environmental field, the so-called triple bottom line. Last but not least, this concerns emphasis of the voluntary nature of socially responsible behaviour, when socially responsible activities surpass the 
framework of obligations given by law. Especially in the case of municipalities, the function of which as defined by the legislation of individual countries includes aspects of SR, it is necessary to emphasize the last of the specified characteristics, this being the voluntary nature of application of the concept of MSR and the fact that it is applied above the framework of the law.

As regards the key term in the definition of SR, this being the term "stakeholders", we understand these to be entities, which influence or are influenced by the behaviour of organizations [21,22]. From the point of view of municipalities, they are usually classified as internal and external stakeholders [23-26]. The broadest range of stakeholders of municipalities is mentioned by Gomes [24], who includes audit commission, central government, contractors, councillors, employees, fire authorities, health authorities, local business, local media, lower tie authorities, management team, other local authorities, partner agencies, police authorities, political parties in general, pressure groups, service users, trade unions, upper tie authorities and voluntary sector among these.

\subsection{Fields and Activities of Municipal Social Responsibility}

In the same way that no uniform definition of SR of an enterprise or in general or any organization exists, neither is there a uniform concept of SR fields and activities. The conventional concept is based on three fields of SR, these comprising the economic, social and environmental field [27,28]. Among others, this concept was applied by García-Sánchez et al. [11] within the framework of analysis of the socially responsible behaviour of Spanish local government. An expanded concept is the concept proposed by one of the most prestigious researchers in the field of CSR, Carroll [2,29], who distinguishes economic, legal, ethical and discretionary (philanthropic) fields. An alternative concept of the fields of SR is provided by Tetrevova [30], who defines economic, social, environmental, ethical and philanthropic fields. The broadest concept of the fields of SR is offered by ISO 26000:2010 which sets out the so-called core subjects: organizational governance, human rights, labour practices, the environment, fair operating practices, consumer issues, and community involvement and development [18]. Yarimoglu et al. [9] define SR fields specifically from the point of view of municipalities, emphasizing the importance of philanthropy and including social support, health, education, culture, the environment, animal, and women's rights among the fields of SR.

Individual socially responsible activities are defined in relation to the fields of SR. A summary of possible socially responsible activities, created primarily for the requirements of corporations, is evident from Table 1. However, it is evident from Table 1 that with one exception, all of the specified activities are also applicable and desirable from the point of view of municipalities. The exception in question is strengthening of relations with owners, when in the case of municipalities, this activity should be replaced with the strengthening of relations with citizens.

Potential socially responsible activities of municipalities can also be identified on the basis of a study by García-Sánchez et al. [11], who examined social disclosure on the part of municipalities on the basis of 72 indicators. We can regard these indicators as possible socially responsible activities of municipalities. Within the framework of the given study, in view of its focus, emphasis is placed on activities relating to ensuring transparency and publication of information. 
Table 1. Summary of socially responsible activities.

\begin{tabular}{|c|c|}
\hline Social & Socially Responsible Activities \\
\hline $\begin{array}{l}\text { Economic responsibility } \\
\text { - } \quad \text { ensuring transparency and openness; } \\
\text { - } \quad \text { care for the quality and safety of goods; } \\
\text { - } \quad \text { streation and implementation of innovations; } \\
\text { suppliers, customers and other stakeholders. }\end{array}$ & $\begin{array}{l}\text { Environmental responsibility } \\
\text { - } \quad \text { saving energy and other resources; } \\
\text { - } \quad \text { minimization of waste and support for recycling; } \\
\text { - } \quad \text { support for preservation of resources and biodiversity; } \\
\text { environmental impacts; } \\
\text { - } \quad \begin{array}{l}\text { encouraging initiatives promoting a responsible } \\
\text { approach to the environment. }\end{array}\end{array}$ \\
\hline \multirow{2}{*}{$\begin{array}{l}\text { Social responsibility } \\
\text { - } \quad \text { ensuring occupational health and safety; } \\
\text { - } \quad \text { care for education and development of employees; } \\
\text { application of measures eliminating any form of } \\
\text { discrimination at work; } \\
\text { ensuring freedom of association in trade unions and } \\
\text { the right to collective bargaining; } \\
\text { implementation of a high-quality process of recruiting } \\
\text { employees and terminating employment; } \\
\text { - involvement of employees in the } \\
\text { decision-making process; } \\
\text { employee care (e.g., employee benefits); } \\
\text { - } \quad \text { work-life balance; } \\
\text { - } \quad \text { combating mobbing and harassment; } \\
\text { ensuring a healthy organization culture. }\end{array}$} & $\begin{array}{l}\text { Ethical responsibility } \\
\text { - installation of a code of ethics; } \\
\text { - } \quad \text { education and training of employees to act ethically; } \\
\text { - } \quad \text { ethical reporting and audit; } \\
\text { creation of an ombudsman's office, an ethics committee, } \\
\text { or a whistleblowing hotline. }\end{array}$ \\
\hline & $\begin{array}{l}\text { Philanthropic responsibility } \\
\text { - } \quad \text { giving, incl. sponsorship; } \\
\text { - } \quad \text { support for donation activities among employees; } \\
\text { - } \quad \text { volunteering; } \\
\text { - } \quad \text { support for individual employee volunteering; } \\
\text { - } \quad \text { collaboration with non-profit organizations; } \\
\text { - } \quad \text { ownership and administration of collections of art or } \\
\quad \text { other collections which should support preservation of } \\
\text { cultural heritage. }\end{array}$ \\
\hline
\end{tabular}

Source: Modified according to Tetrevova et al. [31].

A specific view of the possible socially responsible activities of municipalities is offered by Yarimoglu et al. [9]. Their philanthropic concept of SR of municipalities is evident from the list of their activities. The socially responsible activities of municipalities thus, for example, include disaster assistance, aid for disabled people, soldier family aid, food aid, free second-hand clothes, Ramadan aid, prenatal care, nursing, ambulance assistance, free preliminary courses for students, monetary aid for primary and secondary school students, daily hot meals for students, free hobby and vocational courses, donation of firewood, placement of stay cats and dogs to the shelters, food aid for animals, or health controls of animals.

\subsection{Benefits and Tools for Communication of Socially Responsible Behavior of Municipalities}

The performance of socially responsible activities by municipalities is a source of several positive effects. These can for example be considered to be the best possible satisfaction of needs of urban population and other involved people, provision of high-quality services by increasing the quality of public services, fully informing citizens of ongoing developments in the city, objective resolution of citizenry complaints and disputes, improvement of environmental protection by reducing the negative impact on the environment by the institution, safe and healthy working conditions for employees, limitation of bribery and other forms of corruption, ensuring equal rights (no discrimination concerning age, gender, origin), allocation of funds for philanthropy, stimulation of employees responsibility to society, encourage the spread of good practice, implementation of transparent and social responsible public procurement business and improvement of the reputation of the authority [8].

A condition for successful application of the concept of SR by municipalities is, however, not only development of a suitable portfolio of socially responsible activities, but also their effective communication. This can take place both via municipal and also independent channels [32]. We in particular rank SR reports, annual reports, thematic reports, codes of conduct, municipal websites, internal communication, advertising, prizes and events, media coverage [32-35], official notice boards or public meetings among channels of communication used by municipal authorities. An important role is currently played in particular by websites which make it possible to share information practically 
all over the world with the minimum of costs [36,37]. Internet communication media such as social media sites (e.g., Facebook, Twitter), blogs and chat rooms is also increasing in importance [32,38].

In view of the fact that municipalities finance these activities using public funds, the need to communicate them seems especially important [11]. Thanks to a correctly set process of communication, municipalities can also share benefits relating to the socially responsible activities they perform. Improvement of reputation can be considered to be one of the most important.

\section{Materials and Methods}

The aim of the survey was to identify the socially responsible practices applied by the statutory cities in the Czech Republic, to analyse and evaluate the scope and structure of socially responsible activities performed by them and communicated on the internet. The aim defined above can be narrowed down and specified by the following research questions:

(1) What is the scope and structure of socially responsible activities performed by statutory cities in the Czech Republic?

(2) What is the scope and structure of socially responsible activities communicated by statutory cities in the Czech Republic on their websites?

(3) Do any differences exist in the scope of socially responsible activities which statutory cities in the Czech Republic declare they perform and those that they communicate on their websites?

(4) What is the specific experience from the point of view of statutory cities in the Czech Republic during application and communication of socially responsible activities?

The survey was focused on all 25 statutory cities in the Czech Republic. Further specification of them can be found in Table 2. 22\% of the population of the Czech Republic lives in these cities [39].

Table 2. Characteristics of the research sample.

\begin{tabular}{cc}
\hline Statutory City & Number of Inhabitants as at 1.1.2018 \\
\hline Brno & 379,527 \\
Ostrava & 290,450 \\
Plzeň & 170,936 \\
Liberec & 103,979 \\
Olomouc & 100,494 \\
České Budějovice & 93,863 \\
Ústí nad Labem & 93,040 \\
Hradec Králové & 92,917 \\
Pardubice & 90,335 \\
Zlín & 74,947 \\
Havírov & 72,382 \\
Kladno & 68,804 \\
Most & 66,644 \\
Opava & 57,019 \\
Frýdek-Místek & 56,334 \\
Karviná & 53,522 \\
Jihlava & 50,724 \\
Teplice & 49,563 \\
Děčín & 49,226 \\
Karlovy Vary & 48,776 \\
Chomutov & 48,666 \\
Jablonec nad Nisou & 45,771 \\
Mladá Boleslav & 44,167 \\
Prostějov & 43,798 \\
Přerov & 43,565 \\
Třinec & 35,302 \\
Total & $\mathbf{2 , 3 2 4 , 7 5 1}$ \\
\hline
\end{tabular}

Source: [39]. 
Within the framework of the research, we took our starting point as the national context, when the activity of municipalities in the Czech Republic is regulated by Act No. 128/2000 Coll., on Municipalities. This act determines that a municipality is a public corporation, has its own property and manages its affairs independently. A municipality has the obligation determined by law to care for the all-round development of its territory and for the requirements of its citizens, whereas it should protect the public interest. The act specifically mentions the need for housing, protection and advancement of health, transport and connections, the need for information, education and training, overall cultural development and protection of public property [40].

In compliance with the formulated research questions, the survey was focused on three problem areas, these being MSR activities performed, MSR activities communicated and examples of good practice in performance and communication of MSR activities.

Data for identification of MSR activities performed and for evaluation of the scope and structure of MSR activities performed was in particular gained on the basis of a questionnaire survey. (Use was also made of data gained on the basis of semi-structured face-to-face interviews with representatives of the Statutory City of Pardubice for identification of MSR activities performed.) Some of the advantages of questionnaire surveys are that they make it possible to closely follow the original set of research goals, to arrive at more objective conclusions, to test hypotheses, and to identify aspects of causality [41]. The questionnaire survey was performed in two stages from 15 February until 25 March 2019. In the first stage, all 25 mayors of the statutory cities of the Czech Republic were contacted in the form of a personal e-mail. The questionnaire was available online for 30 days. In view of the fact that the rate of return of questionnaires amounted to only $24 \%$, the heads of the press departments at the municipal authorities were contacted by e-mail in the next stage with a repeated request for completion of the questionnaire. In this stage, the questionnaire was available online for 8 days. The rate of return after implementation of the second stage of the questionnaire amounted to $60 \%$, i.e., 15 completed questionnaires. The questionnaire contained 34 closed questions, on the basis of which the activities that statutory cities in the Czech Republic perform in the economic, environmental, ethical, social and philanthropic fields were identified. While formulating questions, we took our starting point from a modified overview of possible socially responsible activities (see Table 1), also from a modified method of communication of economic, environmental, ethical, social and philanthropic activities (CE3SPA method), which is closely related to this, see [42,43] for more details, but also from the findings which we gained within the framework of semi-structured face-to-face interviews with representatives of the Statutory City of Pardubice. The aforementioned overview and method are primarily determined for evaluation of application of the concept of CSR from the point of view of enterprises. For this reason, they were modified with regard to the activities that do not come into consideration from the point of view of municipalities, see part 2.2. As is evident from Table 4 and Table 5, we ascertained whether statutory cities in the Czech Republic perform (and subsequently also communicate) 34 socially responsible activities, these being 6 economic responsibility activities, 5 environmental responsibility activities, 6 ethical responsibility activities, 11 social responsibility activities and 6 philanthropic responsibility activities. The reason for application of this method was the fact that it respects modern trends in socially responsible behaviour and communication as well as the local conditions.

Data for identification of MSR activities communicated on the internet and for evaluation of the scope and structure of MSR activities communicated was acquired on the basis of content analysis of the websites of all 25 statutory cities in the Czech Republic. Their websites were found with the aid of the Google search engine. This survey was performed from January until March 2019. The reason for choosing websites as the channel of communication under evaluation was, apart from their merits mentioned in Section 2.3, in particular the fact that they provide publicly available data. In addition to this, the expedience of the use of content analysis of websites when mapping the level of socially responsible communication has in the past been confirmed by several studies, e.g., [42,44]. A summative approach to content analysis was chosen, this being based on coding of both key words and also the content of claims [45]. The reason for choosing content analysis was the fact that this 
concerns a systematic, objective and flexible technique [46] which combines aspects of qualitative and quantitative research techniques [47]. Within the framework of coding data, use was made of a binary scale. As already stated, the CE3SPA method was used from a content point of view for identification of socially responsible activities communicated.

Data for the identification of examples of good practice was acquired on the basis of semi-structured face-to-face interviews with representatives of the Statutory City of Pardubice. From the point of view of intensity of MSR activities performed and communicated, the City of Pardubice represents normality in the Czech Republic. However, it does perform a range of interesting and inspirational MSR activities. As is evident from the findings gained on the basis of literature review and website content analysis, these can be regarded as examples of good practice, in both a national, but above all international context. Semi-structured face-to-face interviews with competent employees of 10 specialist departments from Pardubice City Hall were conducted from June until August 2018. The advantage of semi-structured face-to-face interviews is that they are conducted within a framework prepared in advance, yet at the same time provide room for change to the order of questions or for adding questions in reaction to interesting and unexpected answers to the standard questions [48]. They also allow the questioner to explain a question which is unclear to the respondent. Thanks to this flexibility, these interviews are a popular method among several researchers [49]. Interviews focused on five problematic areas, these being fields of SR of municipalities, socially responsible activities performed, organizational provisions for performance of socially responsible activities, motivation for their performance and communication of socially responsible behaviour.

Data gained on the basis of the questionnaire survey and website content analysis was processed using the statistical software package IBM SPSS Statistics, version 24, and MS Excel. Descriptive statistics tools were applied. The intensity of MSR activities performed and communicated was measured with the aid of the average number of activities performed/communicated. The difference in intensity of MSR activities performed/communicated was evaluated with the aid of the relative average number of activities. The structure of MSR activities performed and communicated was analysed with the aid of multiple response analysis.

Data obtained on the basis of semi-structured face-to-face interviews is presented in the form of a case study. A case study "is a kind of research approach in order to investigate and go into a complex issue" [50] (p. 1). This is one of the most appreciated qualitative methods in the field of social sciences [51,52]. A case study of a single, or a small number, of social entities or situations can provide a great deal of, largely qualitative (and also quantitative), data that can be written up as a case study, offering insights into the nature of the phenomena $[50,52,53]$. Use was specifically made of an explanatory case study which allows for explanation of complex phenomena within the framework of a specific context and at the same time allows the researcher to formulate theories and conclusions [52].

\section{Results}

\subsection{Scope and Structure of MSR Activities Performed}

It is evident from the study performed that the statutory cities of the Czech Republic under evaluation perform an average of 27.1 of the 34 evaluated MSR activities, i.e., $80 \%$. A high intensity of MSR activities performed is achieved in the field of economic, social and environmental responsibility. On average, statutory cities in the Czech Republic perform 5.8, i.e., 97\%, of the 6 MSR activities evaluated in the field of economic responsibility. In the field of social responsibility, they perform 10.5, i.e., $96 \%$ of the 11 evaluated activities. In the field of environmental responsibility, they perform 4.7, i.e., $93 \%$ of the 5 evaluated MSR activities. By contrast, the scope of MSR activities performed in the field of ethical responsibility is relatively low. In this field, the statutory cities evaluated on average perform only 1.9 activities, i.e., $31 \%$ of the 6 possible ethically responsible activities. As regards intensity of performance of philanthropic responsibility activities, this can be regarded as relatively 
high. In this field, statutory cities in the Czech Republic implement 4.3, i.e., $71 \%$ of the 6 activities evaluated. See Table 3 for more details.

Table 3. Scope of municipal social responsibility (MSR) activities performed.

\begin{tabular}{ccccccc}
\hline Area & $\begin{array}{c}\text { Number of } \\
\text { Possible } \\
\text { Activities in the } \\
\text { Given Area }\end{array}$ & $\begin{array}{c}\text { Average } \\
\text { Number of } \\
\text { Activities }\end{array}$ & $\begin{array}{c}\text { Relative } \\
\text { Average } \\
\text { Number of } \\
\text { Activities }\end{array}$ & $\begin{array}{c}\text { Median } \\
\text { Number of } \\
\text { Activities }\end{array}$ & $\begin{array}{c}\text { Minimum } \\
\text { Number of } \\
\text { Activities }\end{array}$ & $\begin{array}{c}\text { Maximum } \\
\text { Number of } \\
\text { Activities }\end{array}$ \\
\hline $\begin{array}{c}\text { Economic } \\
\text { responsibility }\end{array}$ & 6 & 5.8 & $97 \%$ & 6 & 5 & 6 \\
\hline $\begin{array}{c}\text { Environmental } \\
\text { responsibility }\end{array}$ & 5 & 4.7 & $93 \%$ & 5 & 3 & 5 \\
\hline $\begin{array}{c}\text { Ethical } \\
\text { responsibility }\end{array}$ & 6 & 1.9 & $31 \%$ & 2 & 1 & 3 \\
\hline $\begin{array}{c}\text { Social } \\
\text { responsibility }\end{array}$ & 11 & 10.5 & $96 \%$ & 11 & 9 & 6 \\
\hline $\begin{array}{c}\text { Philanthropic } \\
\text { responsibility }\end{array}$ & 6 & 4.3 & $\mathbf{7 1 \%}$ & 5 & 2 & $\mathbf{2}$ \\
\hline Total & $\mathbf{3 4}$ & $\mathbf{2 7 . 1}$ & $\mathbf{8 0 \%}$ & $\mathbf{2 8}$ & $\mathbf{2 3}$ \\
\hline
\end{tabular}

The structure of MSR activities performed closely relates to the scope in which MSR activities are performed. In areas in which a high intensity of MSR activities performed is achieved, a significant number of activities are performed by all of the statutory cities in the Czech Republic evaluated. In the field of economic responsibility, all of the monitored cities perform four of the six evaluated activities. This specifically concerns strengthening relations with citizens and companies, strengthening relations with investors, the development of relations with public institutions and membership in associations and partnership with educational institutions. Other activities in this field are performed by at least 13 of the evaluated 15 cities. In the field of environmental responsibility, all of the monitored companies perform three activities, these being saving energy and other resources, minimization of waste and support for recycling and preventing and correcting negative environmental impacts. Other activities in this field are performed by at least 11 of the 15 cities evaluated. In the field of social responsibility, all of the monitored companies perform five activities. This in particular concerns ensuring occupational health and safety, high-quality working environment, care for education and development of employees, application of measures eliminating any form of discrimination at work and implementation of a high-quality process of recruiting employees and terminating employment. Other activities in this field are performed by at least 13 of the 15 cities evaluated. All of the statutory cities also perform collaboration with non-profit organizations, i.e., one of the philanthropic responsibility activities. By contrast, volunteering is performed to the least extent, although this is performed by almost half of the cities evaluated. As regards the field of ethical responsibility, in which the statutory cities of the Czech Republic achieve the lowest intensity of MSR activities performed, none of the MSR activities are performed by all of the cities evaluated. Two of the ethical responsibility activities, these being creation of an ombudsman's office and creation of an ethics committee, are not performed by even one of the cities evaluated. In this field, activity in the form of installation of a code of ethics is performed in the greatest scope, this being by 13 of the cities evaluated. See Table 4 for more details. 
Table 4. Structure of MSR activities performed.

\begin{tabular}{|c|c|c|}
\hline Code & Communicated Activities & $\begin{array}{l}\text { Percent }(\%) \text { of } \\
\text { Cases }\end{array}$ \\
\hline EC & Economic responsibility & \\
\hline EC1 & Ensuring transparency and openness & 93 \\
\hline EC2 & $\begin{array}{l}\text { Care for the quality of public services and creation and implementation of } \\
\text { their innovations }\end{array}$ & 87 \\
\hline EC3 & Strengthening relations with citizens and companies & 100 \\
\hline EC4 & Strengthening relations with investors & 100 \\
\hline EC5 & Development of relations with public institutions and membership in associations & 100 \\
\hline EC6 & Partnership with educational institutions & 100 \\
\hline EN & Environmental responsibility & \\
\hline EN1 & Saving energy and other resources & 100 \\
\hline EN2 & Minimization of waste and support for recycling & 100 \\
\hline EN3 & Support for preservation of resources and biodiversity & 73 \\
\hline EN4 & Preventing and correcting negative environmental impacts & 100 \\
\hline EN5 & Encouraging initiatives promoting a responsible approach to the environment & 93 \\
\hline ET & Ethical responsibility & \\
\hline ET1 & Installation of a code of ethics & 87 \\
\hline ET2 & Education and training of employees to act ethically & 67 \\
\hline ET3 & Ethical reporting and audit & 13 \\
\hline ET4 & Creation of an ombudsman's office & 0 \\
\hline ET5 & Creation of an ethics committee & 0 \\
\hline ET6 & Whistleblowing hotline & 20 \\
\hline SC & Social responsibility & \\
\hline SC1 & Ensuring occupational health and safety & 100 \\
\hline SC2 & High-quality working environment & 100 \\
\hline SC3 & Care for education and development of employees & 100 \\
\hline SC4 & Application of measures eliminating any form of discrimination at work & 100 \\
\hline SC5 & Ensuring freedom of association in trade unions and the right to collective bargaining & 93 \\
\hline SC6 & $\begin{array}{l}\text { Implementation of a high-quality process of recruiting employees and } \\
\text { terminating employment }\end{array}$ & 100 \\
\hline SC7 & Involvement of employees in the decision-making process & 93 \\
\hline SC8 & Employee care (e.g., employee benefits) & 93 \\
\hline SC9 & Ensuring work-life balance & 93 \\
\hline SC10 & Action to combat mobbing and harassment & 87 \\
\hline SC11 & Ensuring a healthy organizational culture & 93 \\
\hline PH & Philanthropic responsibility & \\
\hline PH1 & Giving, including sponsorship & 80 \\
\hline PH2 & Support for donation activities among employees & 67 \\
\hline PH3 & Volunteering & 47 \\
\hline PH4 & Support for individual employee volunteering & 60 \\
\hline PH5 & Collaboration with non-profit organizations & 100 \\
\hline PH6 & $\begin{array}{l}\text { Ownership and administration of collections of art or other collections which should } \\
\text { support preservation of cultural heritage }\end{array}$ & 73 \\
\hline
\end{tabular}

\subsection{Scope and Structure of MSR Activities Communicated}

It is evident from the study performed that all 25 of the statutory cities in the Czech Republic have functioning websites, on which among other things they also provide information about the MSR 
activities they perform. At the same time, 22 of these cities have a link to their communication on social networks on their website (most frequently to Facebook-22 cities; followed by YouTube-14 cities; Twitter and Instagram - 10 cities in both cases) and 19 cities offer RSS channels.

As regards MSR communication on websites, statutory cities in the Czech Republic on average communicate 18.5 socially responsible activities of the 34 activities evaluated. They communicate economic responsibility activities in the greatest scope, this being 5.8 activities of the 6 evaluated activities. On the contrary, they communicate ethical responsibility activities to the least extent, this being 0.8 activities of the 6 evaluated activities. The given findings are also projected into comparison of the intensity of communication achieved in individual areas of MSR. This comparison shows that the greatest intensity of MSR communication is achieved in the fields of environmental and philanthropic responsibility after the field of economic responsibility. The field of social responsibility is a relatively neglected field of communication, in which only $41 \%$ of the 11 evaluated activities is communicated and also, as mentioned earlier, the field of ethical responsibility, in which an average of only $13 \%$ of the 6 evaluated activities is communicated. See Table 5 for more details.

Table 5. Scope of MSR activities communicated on the internet.

\begin{tabular}{|c|c|c|c|c|c|c|}
\hline Area & $\begin{array}{l}\text { Number of } \\
\text { Possible } \\
\text { Activities in the } \\
\text { Given Area }\end{array}$ & $\begin{array}{c}\text { Average } \\
\text { Number of } \\
\text { Activities }\end{array}$ & $\begin{array}{l}\text { Relative } \\
\text { Average } \\
\text { Number of } \\
\text { Activities }\end{array}$ & $\begin{array}{l}\text { Median } \\
\text { Number of } \\
\text { Activities }\end{array}$ & $\begin{array}{l}\text { Minimum } \\
\text { Number of } \\
\text { Activities }\end{array}$ & $\begin{array}{l}\text { Maximum } \\
\text { Number of } \\
\text { Activities }\end{array}$ \\
\hline $\begin{array}{l}\text { Economic } \\
\text { responsibility }\end{array}$ & 6 & 5.8 & $96 \%$ & 6 & 4 & 6 \\
\hline $\begin{array}{l}\text { Environmental } \\
\text { responsibility }\end{array}$ & 5 & 3.5 & $70 \%$ & 3 & 2 & 5 \\
\hline $\begin{array}{l}\text { Ethical } \\
\text { responsibility }\end{array}$ & 6 & 0.8 & $13 \%$ & 1 & 0 & 2 \\
\hline $\begin{array}{l}\text { Social } \\
\text { responsibility }\end{array}$ & 11 & 4.6 & $41 \%$ & 5 & 0 & 9 \\
\hline $\begin{array}{l}\text { Philanthropic } \\
\text { responsibility }\end{array}$ & 6 & 3.8 & $64 \%$ & 4 & 1 & 6 \\
\hline Total & 34 & 18.5 & $54 \%$ & 19 & 10 & 24 \\
\hline
\end{tabular}

In the field of economic responsibility, all 25 of the statutory cities in the Czech Republic communicate four of the six evaluated activities on their websites. This specifically concerns ensuring transparency and openness, care for the quality of public services and creation and implementation of their innovations, strengthening relations with citizens and companies and development of relations with public institutions and membership in associations. In the field of environmental responsibility, all of the statutory cities communicate two of the five activities evaluated, these being preventing and correcting negative environmental impacts and encouraging initiatives promoting a responsible approach to the environment. Minimization of waste and support for recycling is communicated to the least extent in this field; this activity is communicated by only a fifth of cities. In the field of ethical responsibility, in which the lowest intensity of communication is achieved by statutory cities in comparison with other fields of MSR communication, not even one city communicates three of the five evaluated activities. This in particular concerns ethical reporting and audit, creation of an ombudsman's office and creation of an ethics committee. By contrast, the most frequently communicated activity in this field is installation of a code of ethics, although this activity is only communicated by approximately half of the evaluated cities. In the field of social responsibility, activity in the form of care for education and development of employees is most frequently communicated. A relatively neglected activity during communication in this field is action to combat mobbing and harassment. In the field of philanthropic responsibility, all of the statutory cities in the Czech Republic communicate collaboration with non-profit organizations. Activity in the form of volunteering is communicated to a limited extent in this field, be this volunteering performed during working hours, 
or support for individual employee volunteering. These activities are communicated by approximately a third of the evaluated cities. See Table 6 for more details.

Table 6. Structure of MSR activities communicated on the internet.

\begin{tabular}{|c|c|c|}
\hline Code & Communicated Activities & $\begin{array}{l}\text { Percent }(\%) \text { of } \\
\text { Cases }\end{array}$ \\
\hline EC & Economic responsibility & \\
\hline EC1 & Ensuring transparency and openness & 100 \\
\hline EC2 & $\begin{array}{l}\text { Care for the quality of public services and creation and implementation of their } \\
\text { innovations }\end{array}$ & 100 \\
\hline EC3 & Strengthening relations with citizens and companies & 100 \\
\hline EC4 & Strengthening relations with investors & 88 \\
\hline EC5 & Development of relations with public institutions and membership in associations & 100 \\
\hline EC6 & Partnership with educational institutions & 88 \\
\hline EN & Environmental responsibility & \\
\hline EN1 & Saving energy and other resources & 40 \\
\hline EN2 & Minimization of waste and support for recycling & 20 \\
\hline EN3 & Support for preservation of resources and biodiversity & 92 \\
\hline EN4 & Preventing and correcting negative environmental impacts & 100 \\
\hline EN5 & Encouraging initiatives promoting a responsible approach to the environment & 100 \\
\hline ET & Ethical responsibility & \\
\hline ET1 & Installation of a code of ethics & 52 \\
\hline ET2 & Education and training of employees to act ethically & 4 \\
\hline ET3 & Ethical reporting and audit & 0 \\
\hline ET4 & Creation of an ombudsman's office & 0 \\
\hline ET5 & Creation of an ethics committee & 0 \\
\hline ET6 & Whistleblowing hotline & 24 \\
\hline SC & Social responsibility & \\
\hline SC1 & Ensuring occupational health and safety & 24 \\
\hline SC2 & High-quality working environment & 16 \\
\hline SC3 & Care for education and development of employees & 92 \\
\hline SC4 & Application of measures eliminating any form of discrimination at work & 56 \\
\hline SC5 & Ensuring freedom of association in trade unions and the right to collective bargaining & 56 \\
\hline SC6 & $\begin{array}{l}\text { Implementation of a high-quality process of recruiting employees and terminating } \\
\text { employment }\end{array}$ & 36 \\
\hline SC7 & Involvement of employees in the decision-making process & 16 \\
\hline SC8 & Employee care (e.g., employee benefits) & 56 \\
\hline SC9 & Ensuring work-life balance & 52 \\
\hline SC10 & Action to combat mobbing and harassment & 12 \\
\hline SC11 & Ensuring a healthy organizational culture & 40 \\
\hline PH & Philanthropic responsibility & \\
\hline PH1 & Giving, including sponsorship & 88 \\
\hline $\mathrm{PH} 2$ & Support for donation activities among employees & 80 \\
\hline PH3 & Volunteering & 36 \\
\hline $\mathrm{PH} 4$ & Support for individual employee volunteering & 32 \\
\hline PH5 & Collaboration with non-profit organizations & 100 \\
\hline PH6 & $\begin{array}{l}\text { Ownership and administration of collections of art or other collections which should } \\
\text { support preservation of cultural heritage }\end{array}$ & 48 \\
\hline
\end{tabular}




\subsection{A Case Study of Socially Responsible Practices in the City of Pardubice}

Socially responsible activity of the City of Pardubice is, in particular, ensured by Pardubice City Hall. This is made up of the mayor's office, the secretary's office and 10 departments. This specifically concerns the economic department, the department of information technology, the department of property and investment, the department of administrative agendas, the department of education, culture and sport, the department of transport, the environmental department, the department of social affairs, the department of the chief architect and the department of development and strategy.

Other organizations established by the City of Pardubice also participate in ensuring socially responsible activities. This concerns 36 nursery schools, 16 primary schools, 2 primary art schools, 2 youth centres, 2 rehabilitation centres, several cultural organizations (e.g., the Chamber Philharmonic, the East Bohemian Theatre and the Tourist Information Centre), several social service organizations (in particular 2 retirement homes, 1 day care centre and nursing service) and last but not least for example, the Foundation for the Development of the City of Pardubice.

Socially responsible activities are then also ensured by other organizations in which the City of Pardubice holds business shares. This for example concerns Pardubice Public Transport Company (100\% share), Pardubice City Services (100\% share), Dynamo Pardubice Ice Hockey Club (74\% share), East Bohemian Airport (66\% share), the Horse Racing Association (52\% share), the Water and Sewerage Company ( $43 \%$ share) or FREE ZONE Pardubice (30\% share).

The City of Pardubice can be ranked among cities which actively perform and support socially responsible activities. Primary attention is paid to economic responsibility activities. In this field, attention is in particular paid to ensuring transparency and openness in the context of the application of the principles of good governance. An interactive city budget or investment map of the city is thus made available in a user-friendly manner on the city's website. The results of economic management by the city and joint-stock companies with capital participation by the city are also published here. It is possible to watch meetings of the city assembly both live and recorded. Installation of a Senior Citizen's Council and Children's and Student Parliament which act as advisory bodies to Pardubice City Council also contribute towards fulfilment of transparency. Openness of information is ensured via several communication channels. This in particular concerns the website of City Hall, social networks (Facebook and Twitter), RSS channels, electronic notice boards, but also meetings with citizens. Other information channels include the monthly "City Hall Bulletin" or the Czech-English magazine "This is Pardubice" which are distributed free of charge to all households in the city. City Hall also operates an information call centre, City Helpdesk.

Special attention in the field of economic responsibility is paid to the quality, wide availability and innovative nature of public services provided. Among other things, City Hall tries to increase the convenience of services offered, for example with the option of on-line reservation of appointments at the individual offices of City Hall, with an offer of WiFi or free drinking water from dispensers in City Hall buildings. As regards specified socially responsible activities which make up the offer of public services by Pardubice City Hall, this in particular concerns activities from the fields of social services, healthcare and prevention of socially pathological phenomena, culture, sport and development of the city.

Among the specific socially responsible activities in the field of social services, we can for example include the grant program offering financial support in the social and healthcare field, financial support for the Senior Citizens' Centre and Senior Citizens' Club, provision of discount transport within the territory of the city for senior citizens and disabled people in the form of the so-called "senior taxi", operation of a free helpline for senior citizens, support for free legal advice for senior citizens and disabled people, patronage of an emergency service for senior citizens and disabled people or an offer of free interpreting for those with hearing problems during communication with officials. Other activities which fall within this area are for example support for volunteering by senior citizens in nursery and primary schools, support for a city with wheelchair access or a project to ensure affordable housing for citizens in need. 
As regards specific socially responsible activities in the field of healthcare and prevention of socially pathological phenomena, we can in particular list financial aid for Pardubice Hospital for purchase of equipment, the grant programs "Prevention of criminality and increase in safety" and "Fire prevention", support for the program for vision screening and diagnostics for leg disorders among the children of Pardubice, checks on radon in educational institutions in the city or operation of defibrillators on City Hall premises.

As regards specific socially responsible activities in the field of culture, sport and development of the city, this for example concerns the grant program implemented in support of tourism, the program for support of culture, the program for support of sports and the program for support of leisure and educational activities, as well as operation of a business incubator and industrial zone or implementation of a project for starter housing. The City of Pardubice is the co-organizer or financial supporter of several other events, e.g., the Grand Festival of Laughter (a theatre festival), Pardubice Musical Spring, Pardubice Air Show, Czech Open (international festival of chess and games), Pardubice Junior Cup (Czech junior tennis championships), the Golden Helmet (speedway races) or the Great Pardubice Steeplechase (the oldest and most demanding steeplechase in continental Europe).

All of the aforementioned activities are among other things focused on strengthening of relations with stakeholders, in particular the citizens of the city, but also visitors to the city, non-profit organizations which operate in the city or companies which operate in the city or which could operate in the city in the future.

In the field of environmental responsibility, in view of the nature of activity of the entity under evaluation, the range of possible activities is limited. Primary attention in this field is focused on waste management and education of the public. A functional system of waste disposal is ensured using the dense network of containers and eight waste collection sites. The number of containers for separated waste (plastic, paper and glass) is increased on an ongoing basis. Separate collection is also ensured of textiles, biological waste, used vegetable oil from households or small-scale electrical waste. Among other things, a preventative grant program is implemented in the field of environmental education of the public.

As regards the field of ethical responsibility, a Code of Ethics has been installed and is applied in the organization for employees of Pardubice City Hall. Employees are familiarized with this code of ethics via an internal software application.

In the field of social responsibility focused on employees, Pardubice City Hall performs a wide range of activities. Attention is paid to ensuring occupational health and safety, this being both in the form of training when starting work, as well as in the form of regular training courses. Employees also, for example, undergo training in provision of first aid including practical preparation.

Care for a high-quality working environment is also ensured. Employees have at their disposal rooms for implementation of individual work and teamwork. Rooms are simple and airy, emphasis is placed on natural lighting. Regular fluid intake is also ensured for employees with free deliveries of bottled water.

Special attention is paid to the education and development of employees. A broad offer of training courses has been created, be these language courses or courses with computers, as well as management training courses. A training portal is available on which employees can choose from an offer of e-learning courses. Apart from initial training, new employees are also assigned a mentor who helps them to adapt to their new job more quickly and easily.

Attention is also paid to application of measures eliminating any form of discrimination at work. The basic requirement is that employees respect the Anti-discrimination Act. Above the framework of this, the authority also provides its employees—disabled people, pregnant women or parents caring for young children part-time work or flexible working hours. Flexible working hours within the framework of variable blocks of working hours is also offered to all other employees. Work from home is also used in some cases with regard to ensuring work-life balance. 
Pardubice City Hall also implements effective measures to counter mobbing and harassment. These are enshrined both in a code of ethics and also in the work regulations. Attention is in particular paid to prevention of the given phenomena, for example with implementation of training in the relevant communication skills.

Every employee is entitled to join a trade union organization. Among other things, the authority expresses its accommodating attitude towards trade union organizations by allowing them to use the employer's equipment and premises.

While recruiting new employees, the authority attempts to inform the general public in a suitable manner, this usually being via the electronic notice board and website, or via adverts in the press. Transparency of selection procedures implemented in a suitable manner in view of the position being filled is ensured. The appropriate attention is paid to communication both with the selected candidate and also unsuccessful candidates who are informed immediately by telephone or e-mail. Materials provided for the selection procedure are returned to unsuccessful candidates at the cost of the authority. In the event of termination of employment, employees are provided professional help while drawing up the request for termination of employment.

Employees are involved in the decision-making process. Each of them has the opportunity to communicate and discuss their ideas, suggestions or problems at regular meetings or during one-on-one meetings with their superiors. The opinions and evaluation of employees are also identified within the framework of regular anonymous surveys. Emphasis on accommodating and open communication leads to provision of a healthy organizational culture.

Within the framework of care for employees, the authority provides its employees a wide range of employee benefits. This for example includes five weeks of holiday, three sick days, subsidized meals, a contribution towards pension savings, a comprehensive health program within the framework of the cafeteria system, a retirement bonus, option of recreation at the employer's cottage or a discount mobile phone tariff including family members.

Philanthropic responsibility activities by Pardubice City Hall are in particular performed via the following three foundations. The Foundation for Development of the City of Pardubice is intended for support of the economic, social, cultural and sporting development of the city and protection and creation of the environment in the city. The Jan Perner Endowment Fund is focused on support for the development of safe and reliable transport, establishment of high-quality transport and logistics systems and their connection to the European transport infrastructure. The aim of the "Helping Pardubice Hospital" Endowment Fund is to develop the quality and availability of acute in-patient care in Pardubice Hospital and to provide funding for development of modern treatments and equipment. Partnership with non-profit organizations is also developed to a great extent.

\section{Discussion and Conclusions}

SR of municipalities is understood to mean implementation of activities which municipalities perform within the framework of their independent sphere of competence above the framework of the law in economic, environmental, ethical, social and philanthropic fields. This concerns activities that contribute towards development of positive relations with all of the stakeholders and which lead to support for the quality of life of the citizens of municipalities in fields which are not completely usual and expected.

The results of the study show that municipalities can perform analogous SR activities to those performed by corporations. Minor differences are evident in the fields of economic and environmental responsibility. In the field of economic responsibility, there is a logical difference in the amount of attention paid to different types of stakeholders. Stakeholders of municipalities are constituted by key stakeholders, mediators and influencers. Key stakeholders are extremely important for implementation and sharing of the benefits of SR activities performed by municipalities. This concerns citizens, employees of the municipal authority, businesses and entrepreneurs, owners of real estate within the territory of the municipality and donors. Mediators are entities via which SR activities are performed. 
This for example includes the individual departments of the municipal authority, organizations with capital participation by the municipality or organizations established by the municipality. Influencers can have a positive or negative effect on the performance of SR activities by the municipality. This for example concerns higher-level state administration authorities, political parties, lobbies, trade union organizations, partner entities (contractual partners, consultants and financial institutions etc.) or the media. In view of the nature of activity of municipalities, their framework of action is limited in the field of environmental responsibility even though each of the specified activities could be performed in a certain way by these entities too.

It is evident from the study performed that statutory cities in the Czech Republic take an active approach to application of the concept of MSR. On average, they perform $80 \%$ of the evaluated activities. However, they do not use tools for communication of MSR activities, in the form of websites, sufficiently. This is to say that Czech statutory cities communicate only 54\% of the evaluated MSR activities on their websites. As regards the individual fields of MSR, Czech statutory cities perform the evaluated MSR activities to the greatest extent in the economic, social and environmental fields. In the first two cases, these concern MSR activities which are primarily focused on the key stakeholders of municipalities, in particular citizens and employees of the municipal authority. This finding seems logical in the context of the stakeholder theory $[54,55]$. The focus of municipalities on the performance of environmentally responsible activities also seems logical in the context of the current environmental challenges [56-58]. These cities communicate MSR activities in the field of economic, environmental and philanthropic responsibility to the greatest extent on their websites. From the point of view of communication, social responsibility is a neglected field, this being focused on the application of socially responsible behaviour towards the employees of municipal authorities. An especially neglected field, be this from the point of view of performance of MSR activities, but also subsequently web communication, is the field of ethical responsibility. For the sake of comparison, the greatest intensity of SR communication on the websites of enterprises with various areas of specialization which operate in the Czech Republic, be this the TOP 100 companies [42], chemical companies [43,59], sugar producers [60] and gambling operators [61], the same as is the case with municipalities, is achieved in the field of economic responsibility and the lowest intensity of communication is seen in the field of ethical responsibility.

The key motive for the performance of SR activities by municipalities is greater satisfaction of the requirements of citizens, increasing the attractiveness and economic performance of the given municipality and improvement of the reputation of the authority. These aspects subsequently lead to the success of political representation, which is the main bearer of the idea of application of SR activities in municipalities, and re-election of this political representation. A condition for sharing of these benefits is effective communication of SR activities. It is evident from the study that the Czech statutory cities under evaluation insufficiently use the concept of MSR while achieving the aforementioned benefits. Only in the field of economic responsibility is the scope in which statutory cities in the Czech Republic perform and communicate MSR activities on their website the same. In all other areas of MSR, a lower level of communication is achieved. This difference is in particular evident in the field of social responsibility (55\%). A significantly lower difference is then seen between the level of performance and communication in the field of environmental $(23 \%)$, ethical $(18 \%)$ and philanthropic $(7 \%)$ responsibility. From the point of view of specific activities, the greatest difference, achieving a level of $75 \%$ or more, was registered in the case of four social responsibility activities, these specifically being ensuring occupational health and safety, high-quality working environment, involvement of employees in the decision-making process and action to combat mobbing and harassment, and one environmental responsibility activity, this being the minimization of waste and support for recycling. In the case of two economic responsibility activities (ensuring transparency and openness and care for the quality of public services and creation and implementation of their innovations) and two environmental responsibility activities (support for preservation of resources and biodiversity and encouraging initiatives promoting a responsible approach to the environment), it was then proven that the municipalities monitored communicate them on their websites to a greater scope than that 
which they declare they perform them in. The reason for this may be the fact that respondents were not familiarized with the fact that the given statutory city performs this activity. A much graver reason could, however, be so-called SR washing [62,63], i.e., deliberately making false statements about SR activities performed in an effort to achieve better perception among stakeholders, e.g., in the form of greenwashing [64].

In conclusion, we can state that statutory cities in the Czech Republic perform several beneficial MSR activities. As documented using the case of the Statutory City of Pardubice, these MSR activities may represent examples of good practice, even on an international level. However, despite this we can formulate a few recommendations, the adoption of which would lead to an increase in the level of application of MSR practices in the Czech Republic and beyond. First of all, municipalities should review which socially responsible activities they perform and should subsequently consider both how to further extend the range of MSR activities performed and also how to qualitatively increase their performance in the field of MSR. Attention must also be paid to performance of interesting and innovative activities in all of the fields of MSR, i.e., in the field of economic, environmental, ethical, social and philanthropic responsibility. A source of inspiration for municipalities could be examples of good or best practice by municipalities, the authors of which are both domestic and foreign municipalities. Knowledge and experience potential can also be increased in this field thanks to generation and transfer of new knowledge within the framework of associations of municipalities. Municipalities can also learn from enterprises, as the concept of CSR has been discussed and developed for much longer and has been elaborated to a much higher level. We can recommend sharing of knowledge and experience, in particular with multinational companies which can be regarded as leaders in application of the concept of CSR. Another source of valuable findings could be universities, which represent an important creator and disseminator of new ideas.

We can also formulate recommendations for the field of MSR communication. Municipalities should use both conventional tools of communication in the form of notice boards, newspapers and magazines, meetings with citizens, or MSR reports as well as modern tools in the form of websites and social networks (both conventional and professional social networks). Social networks have in particular been increasing in importance in recent years. For example, in the Czech Republic which has a population of approximately 10.58 million [39], Facebook has approximately 5.2 million users and LinkedIn has 1.6 million users [65]. A significant benefit of social networks is that as compared to other communication channels, they improve information gathering and feedback [66]. Municipalities must provide stakeholders information about MSR activities performed via all communication channels in an interesting and user-friendly manner. With use of international frameworks of socially responsible communication, e.g., GRI [67], ISO 26000 [18], or other communication frameworks, e.g., the CE3SPA method [42,43], the MSR indicators which will be communicated should be defined. It is necessary to provide information about inputs, outputs, outcomes and impacts of MSR activities, but also about the development of these indicators over time [68]. Municipalities must provide only truthful and undistorted information about MSR activities performed. The aforementioned sharing of knowledge and experience can also be used within the framework of the communication process. A certain amount of political pressure would certainly also contribute towards an increase in the level of MSR communication as this has proven itself in the past [69]. We can, for example, consider an analogy with the European Union (EU) Directive 2014/95/EU which regulates disclosure of non-financial and diversity information by certain large undertakings and groups [70].

Author Contributions: Conceptualization, L.T.; methodology, L.T.; formal analysis, L.T and M.J.; investigation, M.J.; resources, L.T.; writing—original draft preparation, L.T and M.J.; writing-review and editing, L.T.

Funding: This research received no external funding.

Conflicts of Interest: The authors declare no conflict of interest. 


\section{References}

1. Buchholtz, A.K.; Carroll, A.B. Business \& Society: Ethics, Sustainability, and Stakeholder Management, 8th ed.; Cengage Learning: Mason, OH, USA, 2012; 760p.

2. Carroll, A.B. Corporate social responsibility-Evolution of a definitional construct. Bus. Soc. 1999, 38, 268-295. [CrossRef]

3. Dahlsrud, A. How corporate social responsibility is defined: An analysis of 37 definitions. Corp. Soc. Responsib. Environ. Manag. 2008, 15, 1-14. [CrossRef]

4. Rasche, A.; Morsing, M.; Moon, J. Corporate Social Responsibility: Strategy, Communication, Governance, 1st ed.; Cambridge University Press: Cambridge, UK, 2017; 554p.

5. Bowen, H.R. Social Responsibilities of the Businessman, 1st ed.; Harper \& Row: New York, NY, USA, 1953; 276p.

6. Ahmad, J. Can a university act as a corporate social responsibility (CSR) driver? An analysis. Soc. Responsib. J. 2012, 8, 77-86. [CrossRef]

7. Nejati, M.; Shafaei, A.; Salamzadeh, Y.; Daraei, M. Corporate social responsibility and universities: A study of top 10 world universities' websites. Afr. J. Bus. Manag. 2011, 5, 440-447. [CrossRef]

8. Pauzuoliene, J.; Mauriciene, I. Implementation of social responsibility in public institutions. Soc. Res. 2013, 4, 141-151.

9. Yarimoglu, E.K.; Hacioglu, F.; Gencturk, S.; Kamali, Y.C.; Sayginer, C. A qualitative research on municipalities' social responsibility practices in Izmir City. J. Yaşar Univ. 2015, 10, 75-92. [CrossRef]

10. Vasilescu, R.; Barna, C.; Epure, M.; Baicu, C. Developing University social responsibility: A model for the challenges of the new civil society. Procedia Soc. Behav. Sci. 2010, 2, 4177-4182. [CrossRef]

11. García-Sánchez, I.M.; Frías-Aceituno, J.V.; Rodríguez-Domínguez, L. Determinants of corporate social disclosure in Spanish local governments. J. Clean. Prod. 2013, 39, 60-72. [CrossRef]

12. Crowther, D.; Aras, G. Corporate Social Responsibility. Available online: http://lib.bvu.edu.vn/bitstream/ TVDHBRVT/15839/1/Corporate-Social-Responsibility.pdf (accessed on 9 February 2018).

13. Ipsos. CSR \& Reputation Research 2016. Available online: http://www.cbcsd.cz/spolecenska-odpovednostfirem-ovlivnuje-lidi-pri-jejich-doporucovani-a-rozhodovani/ (accessed on 5 July 2017).

14. Kasparova, K. Faktory Ovlivnuujicí CSR Reportováni, 1st ed.; Masaryk University: Brno, Czech Republic, 2012; 135 p.

15. Tagesson, T.; Blank, V.; Broberg, P.; Collin, S. What explains the extent and content of social and environmental disclosures on corporate websites: A study of social and environmental reporting in Swedish listed corporations? Corp. Soc. Responsib. Environ. Manag. 2009, 16, 352-364. [CrossRef]

16. European Commission. Green Paper: Promoting a European Framework for Corporate Social Responsibility; Office for Official Publications of the European Communities: Luxembourg, 2001.

17. Holme, R.; Watts, P. Corporate Social Responsibility: Making Good Business Sense, 1st ed.; World Business Council for Sustainable Development: Geneva, Switzerland, 2000; 32p.

18. ISO. ISO 26000:2010—Guidance on Social Responsibility. Available online: https://www.iso.org/obp/ui/\#iso: std:iso:26000:ed-1:v1:en (accessed on 15 December 2017).

19. Davis, K.; Blomstrom, R.L. Business and Its Environment, 1st ed.; McGraw-Hill: New York, NY, USA, 1966; 403p.

20. Jones, T.M. Corporate social responsibility revisited, redefined. Calif. Manag. Rev. 1980, 22, 59-67. [CrossRef]

21. Freeman, R.E. Strategic Management: A Stakeholder Approach, 1st ed.; Pitman: Boston, MA, USA, 1984; 276p.

22. Starik, M. The Toronto conference: Reflections on stakeholder theory. Bus. Soc. 1994, 33, 89-95. [CrossRef]

23. Brdulak, A. The role of local authorities in the implementation of the sustainable strategy. Res. J. Univ. Gdaňsk 2017, 66, 55-67. [CrossRef]

24. Gomes, R.C. Who are the relevant stakeholders to the local government context? Empirical evidences on environmental influences in the decision-making process of English Local Authorities. Braz. Admin. Rev. 2004, 1, 34-52. [CrossRef]

25. Steccolini, I. Is the annual report an accountability medium? An empirical investigation into Italian local governments. Financ. Accoun. Manag. 2004, 20, 327-350. [CrossRef]

26. Tooley, S.; Hooks, J.; Basnan, N. Performance reporting by Malaysian local authorities: Identifying stakeholder needs. Financ. Accoun. Manag. 2010, 26, 103-133. [CrossRef]

27. Edgeman, R.; Eskildsen, J. An excellence equation: (E3 governance $+3 \mathrm{E}$ strategy) $\Rightarrow 3 \mathrm{P}$ performance. J. Posit. Manag. 2012, 3, 50-66. [CrossRef] 
28. Mulyadi, M.S.; Anwar, Y. Impact of corporate social responsibility toward firm value and profitability. Bus. Rev. Camb. 2012, 19, 316-322.

29. Carroll, A.B. A three-dimensional conceptual model of corporate performance. Acad. Manag. Rev. 1979, 4, 497-505. [CrossRef]

30. Tetrevova, L. Corporate social responsibility in the Czech gambling industry. Econ. Manag. 2011, 16, 612-620.

31. Tetrevova, L.; Vavra, J.; Bednarikova, M.; Munzarova, S.; Kostalova, J. Společenská Odpovědnost Firem Společensky Citlivých Odvětví, 1st ed.; Grada Publishing: Prague, Czech Republic, 2017; 224p.

32. Du, S.; Bhattacharya, C.B.; Sen, S. Maximizing business returns to corporate social responsibility (CSR): The role of CSR communication. Int. J. Manag. Rev. 2010, 12, 8-19. [CrossRef]

33. Birth, G.; Illia, L.; Lurati, F.; Zamparini, A. Communicating CSR: Practices among Switzerland's top 300 companies. Corp. Commun. Int. J. 2006, 13, 182-196. [CrossRef]

34. Marcuccio, M.; Steccolini, I. Social and environmental reporting in local authorities. Publ. Manag. Rev. 2005, 7, 155-176. [CrossRef]

35. Nielsen, A.E.; Thomsen, C. CSR communication in small and medium-sized enterprises: A study of the attitudes and beliefs of middle managers. Corp. Commun. Int. J. 2009, 14, 176-189. [CrossRef]

36. Bosetti, L. Web-based integrated CSR reporting: An empirical analysis. Symp. Emerg. Issues Market. 2018, 1, $18-38$.

37. Capriotti, P. The World Wide Web and the Social Media as Tools of CSR Communication. In Handbook of Integrated CSR Communication, 1st ed.; Diehl, S., Karmasin, M., Mueller, B., Terlutter, R., Weder, F., Eds.; Springer: Cham, Germany, 2017; pp. 193-210.

38. Schoeneborn, D.; Trittin, H. Transcending transmission: Towards a constitutive perspective on CSR communication. Corp. Commun. Int. J. 2013, 18, 193-211. [CrossRef]

39. Czech Statistical Office. Database of Demographic Indicators for Municipalities of the Czech Republic. Available online: https://www.czso.cz/csu/czso/databaze-demografickych-udaju-za-obce-cr (accessed on 3 January 2019).

40. Act No. 128/2000 Coll., on Municipalities. Available online: www.mvcr.cz/soubor/act-on-municipalities2000-pdf.aspx (accessed on 3 January 2019).

41. Matveev, A.V. The advantages of employing quantitative and qualitative methods in intercultural research: Practical implications from the study of the perceptions of intercultural communication competence by American and Russian managers. Bull. Russ. Commun. Assoc. Theor. Commun. Appl. Commun. 2002, 1, 59-67.

42. Tetrevova, L.; Patak, M.; Kyrylenko, I. Web-based CSR communication in post-communist countries. Appl. Econ. Lett. 2019, 26, 866-871. [CrossRef]

43. Tetrevova, L. Communicating CSR in high profile industries: Case study of Czech chemical industry. Inz. Ekon. 2018, 29, 478-487. [CrossRef]

44. Khasharmeh, H.A.; Desoky, A.M. On-line corporate social responsibility disclosures: The case of the Gulf Cooperation Council (GCC) Countries. Glob. Rev. Account. Financ. 2013, 4, 39-64.

45. Hsieh, H.F.; Shannon, S.E. Three approaches to qualitative content analysis. Qual. Health Res. 2005, 15, 1277-1288. [CrossRef] [PubMed]

46. Elo, S.; Kääriäinen, M.; Kanste, O.; Pölkki, T.; Utriainen, K.; Kyngäs, H. Qualitative content analysis: A focus on trustworthiness. Sage Open 2014, 4, 1-10. [CrossRef]

47. Krippendorff, K. Content Analysis: An Introduction to Its Methodology, 4th ed.; Sage Publications: Los Angeles, CA, USA, 2018; 472p.

48. Mitchell, M.L.; Jolley, J.M. Research Design Explained, 7th ed.; Wadsworth: Belmont, CA, USA, 2010; 672p.

49. Saengpakdeejit, R.; Intaraprasert, C. Reading strategies in foreign language academic reading: A qualitative investigation. Theory Pract. Lang. Stud. 2014, 4, 2599-2608. [CrossRef]

50. Hossieni, S.; Dehkordi, D.J.; Aghapour, A.H. Insights into case study: A discussion on forgotten aspects of case research. Int. J. Sci. Res. Publ. 2012, 2, 1-6.

51. Lee, B.; Collier, P.M.; Cullen, J. Reflections on the use of case studies in the accounting, management and organizational disciplines. Qual. Res. Org. Manag. Int. J. 2007, 2, 169-178. [CrossRef]

52. Zainal, Z. Case study as a research method. J. Kemanus. 2007, 9, 1-6.

53. Easton, G. Critical realism in case study research. Ind. Market. Manag. 2010, 39, 118-128. [CrossRef]

54. Morsing, M.; Schultz, M. Corporate social responsibility communication: Stakeholder information, response and involvement strategies. Bus. Ethics 2006, 15, 323-338. [CrossRef] 
55. Hahn, R.; Kühnen, M. Determinants of sustainability reporting: A review of results, trends, theory, and opportunities in an expanding field of research. J. Clean. Prod. 2013, 59, 5-21. [CrossRef]

56. Aylett, A. Progress and Challenges in the Urban Governance of Climate Change: Results of a Global Survey, 1st ed.; MIT: Cambridge, MA, USA, 2014; 68p.

57. Measham, T.G.; Preston, B.L.; Smith, T.F.; Brooke, C.; Gorddard, R.; Withycombe, G.; Morrison, C. Adapting to climate change through local municipal planning: Barriers and challenges. Mitig. Adapt. Strateg. Glob. Chang. 2011, 16, 889-909. [CrossRef]

58. Sitas, N.; Prozesky, H.E.; Esler, K.J.; Reyers, B. Opportunities and challenges for mainstreaming ecosystem services in development planning: Perspectives from a landscape level. Landsc. Ecol. 2013, 29, 1315-1331. [CrossRef]

59. Tetrevova, L. Communicating socially responsible activities of chemical companies in the Czech Republic. Chem. Listy 2018, 112, 122-127.

60. Tetrevova, L. Communication of socially responsible activities by sugar-producing companies. Listy Cukrov. Repar. 2017, 133, 394-396.

61. Tetrevova, L.; Patak, M. Web-based communication of socially responsible activities by gambling operators. J. Gambl. Stud. 2019. Available online: https://link.springer.com/article/10.1007\%2Fs10899-019-09842-3 (accessed on 30 March 2019).

62. Ettinger, A.; Grabner-Kräuter, S.; Terlutter, R. Online CSR communication in the hotel industry: Evidence from small hotels. Int. J. Hosp. Manag. 2018, 68, 94-104. [CrossRef]

63. Pope, S.; Wæraas, A. CSR-washing is rare: A conceptual framework, literature review, and critique. J. Bus. Ethics 2015, 137, 173-193. [CrossRef]

64. Lyon, T.P.; Montgomery, A.W. The means and end of greenwash. Organ. Environ. 2015, 28, $223-249$. [CrossRef]

65. LinkedIn. Social Media Stats and Demographics in the Czech Republic. Available online: https://www.linkedin.com/pulse/social-media-stats-demographics-czech-republic-jakub-lorenc (accessed on 30 March 2019).

66. Tiago, M.T.P.M.B.; Veríssimo, J.M.C. Digital marketing and social media: Why bother? Bus. Horizons 2014, 57, 703-708. [CrossRef]

67. GRI. GRI Standards. Available online: https://www.globalreporting.org/standards/gri-standards-downloadcenter (accessed on 30 March 2019).

68. KPMG. Sustainable Insight. Unlocking the Value of Social Investment. Available online: https://assets.kpmg. com/content/dam/kpmg/pdf/2014/05/unlocking-value-social-investment.pdf (accessed on 30 March 2019).

69. Romolini, A.; Fissi, S.; Gori, E. Scoring CSR reporting in listed companies-Evidence from Italian best practices. Corp. Soc. Responsib. Environ. Manag. 2012, 21, 65-81. [CrossRef]

70. Directive 2014/95/EU of the European Parliament and of the Council of 22 October 2014 amending Directive 2013/34/EU as Regards Disclosure of Non-Financial and Diversity Information by Certain Large Undertakings and Groups, Official Journal of the European Union L330. Available online: https://eur-lex.europa.eu/legalcontent/EN/TXT/?uri=CELEX:32014L0095 (accessed on 30 March 2019).

(C) 2019 by the authors. Licensee MDPI, Basel, Switzerland. This article is an open access article distributed under the terms and conditions of the Creative Commons Attribution (CC BY) license (http://creativecommons.org/licenses/by/4.0/). 